\title{
Affect in governmentality : Top executives managing the affective milieu of market liberalisation
}

\section{Kantola, Anu Marjaana}

2019-11-01

Kantola , A M , Seeck , H M J \& Mannevuo , M 2019 , ' Affect in governmentality : Top executives managing the affective milieu of market liberalisation ' , Organization , vol. 26 , no. 6,1350508418821002 , pp. 761-782 . https://doi.org/10.1177/1350508418821002

http://hdl.handle.net/10138/310679

https://doi.org/10.1177/1350508418821002

unspecified

acceptedVersion

Downloaded from Helda, University of Helsinki institutional repository.

This is an electronic reprint of the original article.

This reprint may differ from the original in pagination and typographic detail.

Please cite the original version. 
Authors' accepted manuscript for article:

Kantola, Anu, Seeck, Hannele, \& Mannevuo, Mona (2019). Affect in governmentality: Top executives managing the affective milieu of market liberalisation. Organization Vol. 26(6) $761-782$

\title{
Affect in governmentality: top executives managing the affective milieu of market liberalisation
}

\begin{abstract}
This article explores the role of affect in governmentality and develops the concept of the 'affective milieu' to better understand liberal forms of managerial control in market environments. Taking Foucault's writings on consent, security and technologies of self as a vantage point, we suggest that the regimes of governmentality are both rational and affective milieus and propose that the Spinozan-Deleuzian affect theory provides an entry point for exploring how regimes of governmentality operate as affective milieus. The Spinozan-Deleuzian affect theory helps in understanding affective complexities and attempts to create affective alliances in governmentality. Elucidating this point, we explore how top executives at globally operating paper and metal companies entered a new affective milieu when going through market liberalisation. The affective milieu oscillates between the dangers and promises of the market. Using the notion of priming, we analyse how the top executives use the affective threats and promises of the opening markets and how they attempted to develop managerial techniques to incite and orient employees in the new milieu.
\end{abstract}

Keywords Affect, affective milieu, governmentality, priming, Foucault, Spinoza, Deleuze, management, executives, Finland

\section{Introduction}

Although Foucault's writings on governmentality touch on the affective elements in governmental regimes, studies on governmentality have rarely addressed affect. Here, we explore these affective dynamics in governmentality and suggest that the analysis of power's affective aspects could enrich governmentality studies. Drawing on the growing critical 
research on affect in organisational studies (Anderson, 2014; Fotaki et al., 2017; Karppi et al., 2016; Pullen et al., 2017; Thanem and Wallenberg, 2015), we posit that the SpinozanDeleuzian affect theory can especially offer a new perspective on governmentality.

Governmentality regimes are milieus that managers fabricate, organise and design to change human subjects by targeting causes and effects (Foucault, 2007 [1977-1978]: 20-21; Dean, 1999: 33) to encourage active participation (Munro and Randall, 2007: 905). These milieus are usually seen as rational techniques and tactics lacking affective elements. However, there are many elements in Foucault's writings on governmentality that point to the relevance of affect in the workings of power. Governmentality clearly seems to entail an affective side because the regimes of governmentality are based on consenting subjects (Dean, 1999: 22-29; Hindess, 1997). Affectivity is also considered in Foucault's thinking on technologies of self as a part of governmentality (Foucault, 1988: 19; cf. Gutman, 1988; Hutton, 1988). Moreover, Foucault's (2008 [1978-1979]: 66-69) notions of the dynamics of dangers, risks and security in liberal governments touch on the affective side of liberal governmentality. Yet Foucault never discussed the significance of affect or emotion in depth.

In the current article, we propose that the regimes of governmentality are affective milieus that can be productively analysed by connecting theories of governmentality (e.g., Dean, 1999: 125; Foucault, 2007 [1977-1978]: 108) with the Spinozan-Deleuzian theory of affect. Whereas, in Foucauldian terms, governmentality works by creating whole milieus postdisciplinary apparatuses of governmentality in which individuals make decisions (Foucault, 2007 [1977-1978]: 20-21, 2008 [1978-1979]: 259-260) - the Spinozan-Deleuzian affect theory elaborates on this by focusing on the forces, powers, capacities and intensities through which bodies affect and become affected in organisations. Furthermore, the Spinozan-Deleuzian theory highlights the complexities and ambivalences of affect in organisational life arranged through apparatuses of power (Pullen et al., 2017; Thanem and Wallenberg, 2015). Thus, the affect theory offers a productive way of analysing how governmentality works as an ambivalent, open-ended affective milieu.

Specifically, we use Massumi's (2015) notion of priming to understand affective management in these milieus. Mobilising the concept of affect adapted from Spinoza via Deleuze, Massumi (2015: 41) defines priming as a positive form of power - in a Foucauldian sense - that conditions behaviour by implanting presuppositions and activating tendencies in embodied encounters in organisations. Although we are aware of the critiques of Massumi (Pullen et al., 2017: 111), we propose that priming serves as a way to empirically analyse affective governmentality. At the same time, we point out an important reservation. Priming 
does not determine how employees feel because it only encourages and discourages certain passions. In our study, we explore only how the managers attempt to create a particular affective milieu: They do not determine how subjects feel. This perspective questions governmentality as overdetermined technologies of self (Fotaki et al., 2017: 4) and opens up novel ways to explore the affective dynamics in market environments.

The Spinozan-Deleuzian theory suggests that as subjects navigate through complex affective milieus, they may act in unexpected ways (Deleuze, 1988: 17-18; Karppi et al., 2016) and even break out of regimes (Pullen et al., 2017; Thanem and Wallenberg, 2015). Thus, the affect theory helps in perceiving the various subjectivities in organisations and attending to the complexity of power relations (Seigworth and Gregg, 2010: 24); it also emphasises the unexpected potentiality of subjects in terms of moulding life to forms that feel good. Because the critique of sad passions and emphasis on joyful affects is deeply rooted in Spinoza's theory of affections, it can be used to analyse how humans seek joyful passions and avert sad ones (Deleuze, 1988: 26-27; Thanem and Wallenberg, 2015: 241). This offers a new perspective for governmentality studies because it opens the possibility for analysing impersonal affective and economic forces that may increase or decrease our capacity to act.

We elucidate our argument through an empirical study of how Finnish top executives in heavy industries experienced and attempted to manage market liberalisation. Through a case study including interviews with 35 top executives, we explore how the executives initiated shifts that transformed major industrial companies from nationally owned, production-oriented ventures to more market-driven, globalised businesses. Using the notion of priming, we analyse the top executives' experiences with the affective threats and promises of the opening markets, along with how they attempted to develop managerial techniques to incite and orient employees in the new milieu.

We contribute to the studies on affect and governmentality that use the critical organisation theory by developing the concept of the affective milieu to better understand how liberal forms of managerial control work affectively; we suggest that the Spinozan-Deleuzian theory of affect could enrich our understanding of how the Foucaultian regimes of governmentality work as affective milieus in organisations operating in the midst of market liberalisation.

We show how management attempted to employ a wide range of techniques that aimed to target and expand the affective life of the employees (cf. Foucault, 2007 [19771978]: 45) in ways that would make the employees more productive and manageable in the new market environment. We propose that these regimes of governmentality in market 
conditions oscillate between danger and security, and we draw attention to how managers use affective threats and promises to prime their employees affectively. The executives' retrospective accounts of the changes identify the threats and promises that conditioned their actions and inactions, and we suggest that these threats and promises help in understanding the key elements of the affective milieu during the liberalisation process. However, importantly, it must be emphasised that because the present study focuses empirically on these top executives' accounts, we explore only the attempts made by management. Further research is needed to explore how affective milieus work and are experienced from an employee perspective.

Below, we first explore the literature on affective governmentality in market environments. Then, we present our empirical analysis; finally, we provide a discussion of our contributions.

\section{Affective governmentality in market environments}

Foucault (2007 [1977-1978]: 106-07) suggests that starting in the mid-eighteenth century, governments became preoccupied with the economic governance of populations. Liberal governmentality assumed the form of in-depth population management, situating subjects in a social whole, which then became the target of management (Foucault, 2007 [1977-1978]: 101). Thus, governmentality works via the creation of milieus in which individuals conduct and make decisions (Foucault, 2007 [1977-1978]: 20-21, 2008 [1978-1979]: 259-260). These milieus encompass institutions, procedures, analyses, reflections, calculations and tactics that have make the population their target, the political economy as their major form of knowledge and security apparatuses as their essential technical instrument. In governmentality, the subjects themselves play major roles, adopting and developing strategies of self-governance in line with the aims of governance (e.g., Dean, 1999: 125; Clegg et al., 2006: 236).

Contemporary governmentality studies have expanded well beyond Foucault's ideas (e.g., Burchell et al., 1991; Dean, 1999; Miller and Rose, 2008; Rose, 1999). Analyses of governmentality have focussed heavily on the techniques of governance under advanced liberal governments (e.g., Dean, 1999). Typically, governmentality studies have examined rationalities and traced the links among science, knowledge production, calculation and power. At the same time, the affective aspects of governmentality have not been highlighted in either governmentality theories (Burchell, 1993; Hindess, 1997; Miller and Rose, 1998, 2008; Rose, 1999) or management studies (Clegg et al., 2002; Knights and McGabe, 2003; 
Miller and O'Leary, 1987). We, however, suggest that Foucault was not restricted to the rational calculations in governmentality; rather, his writings also point to the affective elements in the regimes of governmentality.

Foucault never explored the significance of affect or emotion in governmentality systematically, yet his writings discuss various aspects of governmentality in ways that refer to the importance of affective dynamics. In governmentality, the technologies of self modulate subjects, helping them adapt to the system (Dean, 1999: 49). Thus, liberal, marketdriven apparatuses of governmentality stand out in their objective of consent creation rather than reliance on subjugation or coercion (Dean, 1999: 22-29; Hindess, 1997; cf. Rose, 1999: 20-60; Seeck and Kantola, 2009). The regimes of governmentality touch on their subjects' inner lives - their motivations, identities and affects (Dean, 1999: 165; Munro, 2012; Lemke, 2001). Thus, the target is a consenting subject who yields to - or even feels for - the system.

Foucault's notion of the technologies of self also suggests that the regimes of governmentality are not restricted to rationalities; they also pertain to the subject's affective life as well. This affective element is particularly clear in confession, a technology of self that interested Foucault early on. In confession, the self-mortifying emotions - guilt, shame and remorse - play a central role because they are sought after and managed to reconstitute a new self (Foucault, 1988: 47-49; 2007 [1977-1978]: 203; Hutton, 1988: 105). Later on, after working on madness and sexuality, Foucault implied that the technologies of self can expand to subjects' affective lives. As Foucault (1988: 18) claimed, in governmentality, the technologies of self permit individuals 'to effect by their own means or with the help of others a certain number of operations on their own bodies and souls, thought, conduct, and way of being'. The aim is to help the individuals 'transform themselves', and this takes place not only rationally, but also in a more fundamental way 'to attain a certain state of happiness, purity, wisdom, perfection, or immortality' (Foucault, 1988: 18).

Also Foucault's (2008 [1978-1979]: 45; 66-69) thinking concerning the dynamics of dangers and security in a liberal government seem to touch on the affective side of governmentality. In liberal societies, systems of knowledge/power are applied to identify and assess the risks and dangers that threaten the population. Consequently, power no longer relies on the sovereign's will; instead, population management develops into apparatuses of security, which address and manage risks while exercising security over a whole population (Foucault, 2007 [1977-1978]: 11; 43-44; 61). These apparatuses are based on rational bodies of knowledge, such as statistics and economic management, but they do not work solely on rationally; instead, they expand into the subjects' inner lives, including affects. As Foucault 
claims, they are 'centrifugal' - they tend to expand and integrate new elements such as 'psychology, behavior and ways of doing things' (Foucault, 2007 [1977-1978]: 45). Thus, reading Foucault's accounts on the society of security, the tension between dangers, risks and security becomes an inherent affective feature in liberal governmentality regimes.

However, although Foucault touched on governmentality's affective elements when writing about consent, the technologies of self and the apparatuses of security, he did not systematically develop the affective sides of governmentality. Thus, we suggest that studies of governmentality could consider affect in governmentality more carefully; especially useful here, Spinozan-Deleuzian theories of affect could provide one way to explore the affective aspects in governmentality.

\section{Spinozan-Deleuzian theories of affect in regimes of governmentality}

The Spinozan-Deleuzian affective theory provides an interesting way to study governmentality regimes. Spinoza (1994 [1677] IIIP6: 7-8) saw individuals as driven by conatus, a term borrowed from the Stoics, suggesting that each thing strives to maintain its being. Spinoza's notion of affect is based on his understanding of human beings as interdependent with and open to others. In Ethics, Spinoza (1994 [1667] IIIDef.3) defines affect as the 'affections of the body by which the body's power of acting is increased or diminished, aided or restrained, and at the same time, the ideas of these affections'. This notion is ingrained in his understanding of individuals as interdependent, relational beings embedded in a system where they are always open to others, affected by others and affect others by their actions. As he states, 'nothing exists from whose nature some effect does not follow' (Spinoza, 1994 [1677] IP36).

Spinoza's thinking has been applied in recent social and cultural theorising on affect to overcome the dualism of personal and collective emotions (Karppi et al., 2016; Seyfert, 2012; Thanem and Wallenberg, 2015: 237). The Spinozan understanding suggests that affects should not be studied as individual feelings, emotions or bodily actions; rather, they should be viewed as complex, dynamic milieus in which individuals influence each other. In other words, one's affective life should not be reduced to either personal feelings or collective emotions (Brennan, 2004; cf. Michels and Steyaert, 2017). Instead, human bodies influence others in various ways via active affects ranging from sad to joyful passions that may enhance or diminish bodies' capacities (Thanem and Wallenberg, 2015: 241). In addition, it should be noted that Spinoza did not restrict affect to emotions but included both reason and emotion 
without making hierarchical distinctions between them (Thanem and Wallenberg, 2015: 241242). Thus, both the Foucauldian and Spinozan theories indicate that power works through reason and affect.

In our case, we are especially interested in how the Spinozan view of affective life can be employed in studies of governmentality. The Spinozan understanding of affective life has primarily been mediated in the affect theory through Deleuze, who engages with Spinoza's philosophy by emphasising the force of conatus. For Deleuze (1988: 21), conatus is the central, unconscious bodily force behind affective encounters that moves bodies into affective relations with other bodies as humans seek joyful passions and avert sad ones (Deleuze, 1988: 26-27; Thanem and Wallenberg, 2015: 241).

The Spinozan-Deleuzian affect theory suggests that power works in affective milieus not through issuing orders and disciplining subjects, but rather through conditioning subjects to increase or diminish certain actions. The theory emphasises that the body's ability to affect and be affected is not fixed (Massumi, 2015: 103). In the Spinozan-Deleuzian affect theory, bodies are not entities; rather, they are viewed as assemblages with bodily capacities (Karppi et al., 2016: 3). When one body encounters another, the two can combine and form a more powerful whole; alternatively, one can break the other apart (Deleuze, 1988: 17-21; cf. Thanem and Wallenberg, 2015: 240-242). Affective encounters may give rise to a variety of affects 'depending on whether the thing encountered enters into composition with us' (Deleuze, 1988: 21). Because the outcomes are not strictly predetermined, the theory leaves space for subjects to feel and act in unexpected ways; when subjects are driven by their conatus, nothing is certain, and there can be surprising outcomes.

For Foucauldian theories of governmentality, the Spinozan-Deleuzian theory presents a dynamic and complex view of the subjects' affective lives, perhaps more so than the theories of consenting subjects in disciplinary regimes because these theories have been criticised for their determinism. ${ }^{i}$ Power regimes emerge from contradictions, paradoxes, flows and surprises as affective milieus create attachments, which, as we suggest, are ambivalent and complex. This ambivalence does not make management less powerful; rather, it unfolds the complexities and unexpected and contradictory dynamics of the affective milieu. To preserve one's being, one may adopt various techniques that can be felt in a number of ways, from excitement to fear of losing one's job. The Spinozan-Deleuzian theory also offers possibilities for reparative readings (Sedgwick, 2003) that highlight the ambivalences in encounters instead of 'revealing' systemic oppressions (Fotaki et al., 2017: 5-6). 
This view of affective life is especially strong in market environments, the principal realm of Foucauldian governmentality. Market-driven regimes rely on indirect forms of control that rather than acting directly on individuals, sustain the socioeconomic milieus in which they emerge (Foucault, 2007 [1977-1978]; Gordon, 1991; Weiskopf and Munro, 2012). Thus, technologies of governmentality serve to mitigate the freedoms of liberal principles and their attendant risks (Miller and Rose, 2008; Weiskopf and Munro, 2012). In these principles, the subjects are free to act as they will, so instead of imposing rules and discipline, the regimes need to make subjects strive for something. Thus, we suggest that the Spinozan-Deleuzian view can be used to understand the market regimes of governmentality as complex affective milieus with no determined outcomes.

How should one empirically study the management of complex affective milieus? Massumi (2015) suggests the notion of priming to explain how power works in these milieus. As a form of power, priming conditions certain behaviours by implanting presuppositions and activating tendencies in embodied encounters; it incites and orients subjects, modulating rather than moulding (Massumi, 2015: 41). For Massumi (2015: 29-30), priming also describes the affective workings of managerial strategies. It is the art of management, taking place before events happen and representing 'the royal way to the modulation of events before they fully emerge' (Massumi, 2015: 30). Accordingly, priming occurs when management implants presuppositions and creates a milieu that activates and triggers employees to behave in certain ways. Subjects are modulated to act appropriately through conditioning triggers, such as threats of layoffs and promises of communal feelings created by a sense of belonging.

Priming provides a way of empirically examining the management of affective milieus because it allows for studying how subjects are encouraged to flourish in organisations. Spinozan-Deleuzian affective milieus are characterised by passions that encourage or diminish the possibilities for action: joy increases the ability for acting, whereas sadness diminishes the power of acting (Deleuze, 1988: 50). Starting from this premise, priming can involve threats, which may create sad passions and resentment, or optimistic promises, which may increase hopefulness and joyful encounters (cf. Seigworth and Gregg, 2010: 13). Threats create a sense of fear, alarm and danger, discouraging subjects from behaving in certain ways; promises encourage certain actions, leading to harmony with others.

However, we must note an important reservation. Although priming works through encouraging and discouraging certain passions, it does not determine them. This is a pressing issue for affective governmentality because governmentality has been criticised for holding an overdetermined view of technologies of self, which make subjects passively adopt market- 
driven imperatives into their subjectivities. Thus, it needs to be stressed that affective governmentality does not determine what subjects actually feel; in other words, managers cannot determine how their workers feel. Therefore, management by priming involves the managers' attempts to build an affective milieu that creates feelings of belonging, as well as the workers' experiences with how affective management actually feels for them. This limitation is especially important in light of the criticism that governmentality promotes an overdetermined view of technologies of self, which all too easily views subjects as passive adopters of governmental imperatives into their subjectivities. In this view, affect destabilises and unsettles earlier ideas of governmentality (Fotaki et al., 2017: 4) and opens more possibilities to rethink how affective milieus work, especially in market-driven environments.

\section{Case study: affective governmentality in heavy industries}

Our case study explores how 35 Finnish top executives in globally operated metal and paper industries managed the fundamental transition from national markets to global industries amid financial and market liberalisation. Between December 2007 and March 2008, we interviewed 35 senior managers from four large corporations listed on the Helsinki Stock Exchange (NASDAQ OMX Helsinki). We were especially interested in the rise of market-driven management practices, so we chose to interview experienced top executives who had worked in their industries during recent market-driven changes in the past decades.

Historically, the metal and paper industries have been the crown jewels of Finland's economy. Finnish industrialisation in the mid-nineteenth century was largely founded on iron and forest products, which still account for a large share of Finnish exports. However, in recent decades, market globalisation has transformed all the companies in these sectors (Lilja and Tainio, 2006). In the 1960s and 1970s, these companies (or their predecessors in the case of companies that merged) expanded heavily into foreign markets, and amid financial liberalisation during the 1980s, foreign investments in Finnish firms grew steadily (Fellman, 2003; Lilja and Tainio, 2006). Consequently, these companies experienced major structural transformations. They grew rapidly in size, adopted new organisational models, took steps towards internationalisation and emerged as global leaders in their fields (Hjerppe and Larsson, 2006).

These shifts affected the industry's position in Finland. As in Sweden, the Finnish paper and metal industries had closely cooperated with the state, especially since the late 1960s, when they bargained for wages in centralised trilateral negotiations characterised by a social partnership ideology (Anthonsen et al., 2011; Lijphart, 2012: 166). Market 
liberalisation brought this centralised form of corporatism into question, prompting discussions on the decline of corporatism (Lindvall and Sebring, 2005). Corporatism, however, did not disappear with market liberalisation; instead, it took on new forms (Christiansen, 2017). Our case study takes place in the context of a corporatist system that has experienced turbulence under market liberalisation and explores the top executives' perspectives on these changes.

We interviewed experienced chief executive officers, general directors, company board chairpersons and executive group members (see Appendix 1 for the company profiles and Appendix 2 for the interviewees' profiles) responsible for imposing system aims and requirements on employees. The interviewees included 24 executives from two metal companies and 11 executives from two paper industry companies. Negotiating access to interview executives was enabled by financial support from a respected academic funder - the Academy of Finland - and one researcher's fellowship in a business think tank. After the first companies' executives joined the research, it became easier to convince the executives from the other companies to take part. Considering that affectivity usually touches on sensitive matters and seeking to prevent possible ethical dilemmas in the research process, the ethical board of the researchers' organisation was involved throughout the study, for example, in examining all the interview guides. Moreover, at the beginning of the interviews, all the interviewees signed individual contracts listing their rights (e.g., the right to terminate the interview at any time). Most interviews lasted 80-100 minutes and took place either on the company's premises or at the executives' homes, depending on their preferences. Most interviews occurred in a pleasant, relaxed atmosphere.

All the interviewees had had long careers in their companies, and they represented several generations of managers. During the interviews, we asked them to look back at the changes in their work and companies throughout their careers and to describe the critical turning points in their companies' histories and the implications these turning points had for their businesses and management. To do justice to the executives' accounts, they were allowed to explain their views on these topics and experiences freely and focus on the themes they found important. Articulating one's ideas is not a simple process, but the interviewees constructed clear images of their views and experiences.

Considering the data limitations, an important limitation of the data is that memories may fail: Retrospective accounts should not be taken as historical fact. Thus, we do not describe historical trajectories but instead explored how the leaders who lived through these changes made sense of them and adopted certain techniques to manage their employees. 
Moreover, as mentioned earlier, from the perspective of management, the executives' views were merely attempts at creating an affective milieu and did not ensure that their workers actually acted accordingly. We do not study what the subjects actually felt and how they acted upon their affects. Instead, we analyse the managers' attempts to create an affective milieu by asking how they aimed to control action: How did they make threats, and what promises did they give? Thus, the interviews yielded a good picture of the managers' attempts to create an affective milieu by asking how they aimed to control action - that is, what threats and promises they made.

After reading the interviews several times, we classified them from the priming perspective and focussed on how the executives described the imperatives for action and nonaction in their management for modulating employees' actions with conditioning triggers (Massumi, 2015: 29-30). The executives frequently discussed the imperatives that made firms behave in certain ways and described the threats or promises that drew their attention by eliciting their affective reaction (Seigworth and Gregg, 2010: 16). Thus, we focussed on the threats and promises that the executives recalled as compelling them to take or refrain from certain actions. Below, we recount the threats and promises in the executives' stories and describe the affective atmosphere that became visible as the executives recounted their experiences of market liberalisation.

\section{Analysis}

We read the executives' accounts as a regime of Foucauldian governmentality and use the Spinozan-Deleuzian affect theory to highlight the affective elements in corporate restructuring as market forces pose new threats and promises for their companies. Especially, we explore how the Foucauldian dynamics between dangers and security (Foucault, 2008 [1978-1979]: 66-69) surface in the executives' accounts and how they can be seen not only as rationalities, but also as affective forces, and in the Spinozan-Deleuzian reading, affectivities that avert sad passions and seek joyful passions (Deleuze, 1988: 26-27; Thanem and Wallenberg, 2015: 241).

\section{Facing the threat: the sadfeelings of the market}

As Foucault (2008 [1978-1979]: 66-69) suggests, an all-pervading sense of danger is a central tenet of liberal regimes. Accordingly, in our case, the executives recalled how the globalised markets posed a new life threat for their companies. Quoting one interviewee, who had studied Finnish and Swedish paper companies' annual reports and noted that a market- 
oriented approach had overtaken earlier management strategies, 'A company that relies on this [engineering] management model will not survive, but go bankrupt' (Company $\mathrm{C}$, interview $1)$.

In Finland, the market dangers materialised when the markets were liberalised in the 1980s, and the fall of the Soviet Union in 1991 ruptured the largely state-led and coordinated trade with the Soviet Union, which had played a major role in the national economy, contributing to one-fifth of the country's foreign trade. The liberalisation of capital movements led to a financial crisis and major recession in the early 1990s, after which Finland joined the European Union (1995) and adopted the euro (2002). All this pushed industries to restructure their corporate strategies in a new environment of market liberalism and intensified competition.

The executives' accounts of the change depict a sense of rupture as the new dangers of the market materialised. As one executive notes, there was no alternative; the rupture forced the executives to downsize the organisation and sell parts of the businesses:

In the 2000s, the situation became such that we could no longer develop everything. ... Because of the scarcity of both capital and management resources, we had to choose what we would concentrate on. And that is when selling parts of businesses and focusing our investments and operations on particular areas started. This was a clear strategic change. (Company A, interview 4)

Consequently, a wide range of new rationalities were employed in management. In the 1980s, the companies introduced a range of management techniques focusing on efficiency and 'rational management'. New systems of strategic management emphasising core competencies, restructuring and customer needs were established. Quality management systems, especially Total Quality Management (TQM,) became increasingly popular in the 1990s, and performance-related pay, along with employee responsibility, became dominant in the 2000s.

In the Foucauldian reading, all these management techniques can be seen as forming a new type of governmentality regime in the face of market threats, resulting in new rationalities of power (Seeck and Kantola, 2009). Strategic management, the pursuit of core competencies and the use of information technology data as a management tool - drove systemic changes and organisational restructuring, resulting in terminations and layoffs, administrative downsizing and a greater focus on the company's core competencies. In practice, various units were forced to highlight core competencies, and their effectiveness was 
monitored more closely compared with earlier times. Individual employees and their productivity were scrutinised more carefully. Workforces were reduced, hierarchical layers and functional departments were eliminated, and almost all activities except perceived core competencies were outsourced. Initially, outsourcing affected support and specialist functions, but in the 1990s, functions closer to the core of organisations, such as engineering and manufacturing, were outsourced.

These new rationalities emphasised the market's power - the relevance of the buyer in relation to the seller and satisfaction of the customers' needs. This type of milieu is typical of liberal governmentality (Dean, 1999), where the circulation of capital, especially human capital, and, most importantly, competition are encouraged (Munro, 2012). These tactics created the 'rules of the game', constituting the milieu in which individuals (entrepreneurs) could make better or worse decisions based on their costs (Weiskopf and Munro, 2012: 690). The liberal techniques of governmentality can be viewed as technologies of performance (Munro, 2012) and 'responsibilization' (O'Malley, 2008: 276) aimed at creating the enterprising self (Du Gay et al., 1996).

At the same time, thinking affectively, these technologies work as technologies of security that can counter the all-pervasive feeling of the danger characteristic in market environments. For Foucault (2008: 66-69), the fundamental affect of liberal order paradoxically is an all-pervading sense of danger. When subjects are liberated, no sovereign ruler or disciplinary power can guarantee security within a given system. Subjects need to stay vigilant, monitor their environments and mould their identities and behaviours to counter dangers and minimise risks. Liberal governmentality addresses these dangers by creating security apparatuses and processes of control that mitigate these dangers by developing normalising, therapeutic and training technologies of agency. Accordingly, although the new management tactics clearly imposed new rationalities on employees, the executives' accounts also describe how the changes materialised affectively in the dangers and risks posed by the market. Layoffs were a shocking experience not only for those who were fired, but also the management and those remaining: Everyone knew they could be next. Although the change was 'traumatic', the executives felt the need to stand firm and maintain the line because there was no alternative:

About 10 per cent of the personnel were laid off in one go, which was a fairly traumatic experience. Nothing like that had happened in the company before. 
But it was purely because of market needs and was done so that we could make our structures more competitive. (Company A, interview 14)

Similarly, another manager describes encounters that made the employees understand the threats of the market and the rationale behind the new techniques while increasing their sense of security; thus, these techniques were approved by the staff:

Everybody realised that a company that is highly profitable is also good for the staff, that it can guarantee jobs and security and that by all these means that the business can grow. In this way, we could get many difficult decisions approved, such as the sales of different sectors and factory closures. (Company A, interview 12)

These formulations suggest an affective milieu of management where the threats of the market became a harsh force, which made the staff approve layoffs. These techniques, which calculated the market and profitability of different operations, however, worked not only as rational tactics of governmentality, but also became an affective force as security apparatuses (Foucault, 2008 [1978-1979]: 66-69). As the executive explains, from management's viewpoint, the workers approved of the harsh market rationalities, such as factory selloffs and closures, as good for the staff, guaranteeing jobs and security.

Another important element in the new affective milieu of market threats was the changing status of strikes. Strikes -workers' ultimate weapon and the affective high point of worker relations in the earlier age of national corporatism and trilateral wage negotiations became seen as major threats to organisations' existence. Executives expressed that strikes as the 'old normal' caused serious harm to industries in the 'new normal' because they diminished firms' reliability from the customers' perspective. Now, strikes needed to be avoided at any cost if workers were to keep their jobs and companies were to stay in business. One executive described how strikes threatened the whole company because customers should never be disappointed. In the new conditions, management attempted to make people think of strikes as a threat for the whole existence of the company and to diminish workers' horizons of action considerably. This stance becomes clear in one executive's account as he lists a number of things that will be lost and closed if the workers go on strike:

Our competitive situation is such that if you say that customers expect to get the products as promised, and if we say that we have agreed that these are our employment terms and conditions and then go on strike, it means that the whole 
thing will collapse. This means that the company will gradually lose its competitive edge, and [...] companies that cannot deliver as agreed will gradually go out of business. The factory will close its doors. It's quite a challenge to make people understand what this is all about. (Company B, interview 7)

Overall, the market thus created a new, harsher affective milieu, sharply contrasting the earlier days of growth and relatively stable employment: One needed to feel concerned, cautious or fearful regarding market forces and maintain a disciplined mindset and actions in the face of danger. This market and its dangers became an affective force that could, in Spinozan terms, foster sad passions such as pain, fear and insecurity that, again, diminish the body's capacities to act (Deleuze, 1988: 50; Thanem and Wallenberg, 2015: 241). For management, it meant that because no sovereign ruler or disciplinary power could guarantee security in liberal markets, the managers needed to create systems where the subjects needed to focus on 'self-manag[ing] their prime encounters' (Massumi, 2015: 32) by navigating through and staying alert to these encounters. Here, employees were targeted by management methods that controlled their actions in more detail and cut out a range of actions and functions deemed as unnecessary or even harmful, including worker strikes, which were perceived as especially threatening to the companies.

Turning threats into promises: attempts for joyful affections in the market environment

Threats were, however, only one side of the management system. Besides emphasising the dangers of the markets, management sought - as the Spinozan-Deleuzian framework suggests to emphasise joyful passions and hope, hence downplaying sad feelings (Deleuze, 1988: 50; Thanem and Wallenberg, 2015: 241-42). These attempts to encourage joyful passions surfaced in the managers' accounts in various ways. First, the managers did not let the threats and dangers prevail as the dominating force, but also saw a range of positive promises in the market environment. Despite the harsh market conditions and tough competition, all the top executives embraced market liberalisation. The executives displayed positive affective attunement towards the fall of the Soviet Union and the whole Eastern bloc, which they viewed as liberation from a state-bound economy, opening new markets and giving them the freedom to pursue customers:

It was quite a change, which we in Finland greeted positively - or perhaps the politicians didn't because they had had this glamour when they had been toasted for all these New Year's deals and so forth. But for the companies, it was a very good thing. 
This meant that we were able to speak with the customers and develop their businesses as well. (Company D, interview 3)

For the executives, these historical changes and the growing market threat promised liberation from national corporatism, unions and policy bargaining. The previous affective milieu was characterised by national symbiosis and paternalist leaders who had great power over companies. This milieu was described as tense, governed and filled with 'sad passions' (Deleuze, 1988: 26), such as hatred and class antagonism between leaders and workers. In this milieu, strikes served as a powerful weapon for the workers, who also had strong affective alliances through trade unions. Moreover, the national government had a powerful role because it supported collective wage agreements. The strongest tool in the government's kit was the devaluation of the national currency (the Finnish mark). Bilateral trade with the Soviet Union, negotiated through 5-year agreements, further increased the national government's importance in labour relations. Many executives viewed the past as a time of sad feelings, as a milieu in which everything could be manipulated. The new need to consider political negotiations created a sense of frustration among the executives:

But this devaluation was not the only thing. It was that in the whole Finnish paper industry, there had developed this kind of idea - should I say, culture - that all things could be manipulated. It meant that during this time period, say, from 1970 to 1990, it was not possible to create this kind of genuine, open business culture. Instead, everything was based on this idea of devaluation and the idea that all things can be manipulated. (Company $\mathrm{C}$, interview 1)

Thus, market liberalisation was seen as a positive change and a step towards a new affective environment filled with new open encounters, which the executives could use as a source for active and empowering feelings. In other words, their capacity to act increased as new encounters preserved their degrees of power (Deleuze, 1988: 99). The executives' recollections clearly reflected these dynamics, suggesting that the change was a possibility for new joyful encounters that 'tend[ed] their tendings' (Massumi, 2015: 32) and brought them near the 'bliss of action' (Deleuze, 1998: 28). In a way, the joyfulness of the open business culture was an affective passing of a threshold for them, providing them with new capacities (Massumi, 2015: 103) opposite those of the business culture conducted in state-led negotiations.

Another way of trying to move towards joyful passions was developing management techniques that downplayed sad feelings and aimed to instil and increase joy and positive 
feelings in the affective milieu. The executives saw and felt the darker side of the market threats: As the pace of work increased in tightened competition, there was a danger of people overworking and losing their motivation because of exhaustion, sadness and other passages to resentment and the diminution of power (Deleuze, 1988: 50) because sad passions often diminish one's capacities (Thanem and Wallenberg, 2015: 241). As one executive recalls in the following excerpt, the managers tried to develop techniques that would make the staff work hard but not become exhausted:

One very important matter is the question of ensuring that skilled staff are as productive as possible. Then, there are these management methods and matters concerning managerial skills. How can we make these people work as hard as possible without making the place a sweatshop and without them becoming totally exhausted? (Company C, interview 4)

Thus, management needed techniques that would not only provide threats as rationalities of action for the subjects to behave in a certain way, but also that would keep employees functioning and productive to avoid exhaustion. The executives did not leave these concerns untouched; rather, they turned towards techniques that attempted to foster positive affects in the organisation. These techniques relied on a motivational and communicative positive psychology aimed at inspiring motivation, communication and communal feelings. Thus, a considerable range of positive management techniques - such as job shifting initiatives, personal rewards systems and more education for middle management - was employed to attempt to drive employee engagement. These management initiatives were also making promises of a more egalitarian work life as hierarchies were flattened, and most executives claimed that it was effectively impossible to be a high authority figure. Executives emphasised that they no longer dictated; they now discussed matters, involved the team in their work and set a model of teamwork for the whole organisation (Company A, interview 1). One executive described this management style as follows:

This new and more cooperative style of management is better. These days, executives are professionals who come from outside the company, and that is all well and good. The leader does not need to know a specific technical process; instead, his human relations skills are more important. (Company A, interview 4) 
Companies also tried to encourage spontaneous initiative-taking by suggesting that workers should report issues that could be improved. Management also tried to favour delegation and tolerate incidental mistakes. After all, priming requires participation, which allows things to come out, instead of punishment, which would push things down and diminish communal action (Massumi, 2005: 30). Thus, workers were conditioned by the promise of a work life in which they were egalitarian, active subjects:

The worst thing is an organisation that has no initiative-taking. Nothing develops anywhere. If workers cannot do things by themselves, it suffocates any initiativetaking. If one always bangs one's head on the wall, a sensible person does not do it very many times. After that, one just does things because 'I'm forced to do this'. (Company B, interview 3)

Ideally, the target was a management system where improvements came from employees and were not imposed from above, as in centrally organised management schemes. As another executive described, the management aimed to reconstitute the workers' subjectivities to let the employees show themselves how good they were. He described this human-centred management's affective rationality as follows:

The ultimate goal of management is to turn workers from objects into subjects. One needs to let people show themselves and others how good they are. That motivates and creates incentives for workers. (Company $\mathrm{C}$, interview 1)

The aim was to create employees who would be motivated from within, turning them 'from objects to subjects', as one executive put it (citation above), which resonates with the Foucauldian understanding of liberal regimes as milieus of consenting and productive subjects. These new management techniques can be seen as affective technologies of self (Foucault 1988: 18), which pertain to the inner lives of the employees, suggesting that individuals were to transform themselves both rationally and affectively to attain a motivated or inspired state of mind. In the Spinozan-Deleuzian view, the new management techniques tried to diminish the prevalence of sad passions and increase the body's abilities to act so that the bodies would create a milieu filled with possibilities for joyful encounters with others (Deleuze, 1988: 26-27; Thanem and Wallenberg, 2015: 241).

In addition, feelings of belonging also became a major target for management. Again, the enhanced market threats seemed to alter the management of communal feelings. In earlier 
times, company managers had attempted to instil feelings of belonging with a paternal system, where managers personally addressed workers by name and the family owners of one company played a major role in cultivating a sense of family feeling among the workers. As companies grew in size and began to operate globally, managers became concerned with the weakening feelings of belonging. Worker relations changed as business operations and industrial production increasingly internationalised, and companies needed flexible team players from all over the world to develop and market new products globally. Some executives feared that workers would lose whatever affective liaisons they had with the company, instead becoming 'cogs' in a machine without knowledge of the 'bigger picture', thereby diminishing motivation and commitment. As one commented:

Now, we have only one data system for this function, and in principle, these things can be made in Krakow or anywhere else. This means that these work communities will no longer be responsible for these functions because they will be transferred to faraway places. All parts of the organisation will be practically identical. This is straight talk, but I want to make sure that you know what I mean. It will be similar to what it was in the sixties; in other words, it will become totally functional. And my view is that in big companies, this has already affected motivation because you no longer feel that you have anything to do with the company as a whole. (Company $\mathrm{C}$, interview 6)

Consequently, when faced with these threats, the chief executive officers and company headquarters, the symbolic centres of dispersed organisations, developed management policies that tried to tackle the evaporating communal feelings and instil a new kind of common spirit and feelings of belonging (Company $\mathrm{C}$, interview 6). Teamwork was introduced as a new form of work, creating opportunities for employees to experience new, team-based communal feelings, bypassing the corporate spirit, which had been the main feeling of the nationally grounded industries. One executive described how he perceived that the company spirit gave way to team spirit in the corporation:

The common spirit was not so strong as it is nowadays. I mean, of course, the company name was well-known, and it was great to work there [laughs]. But still, inside the company, there were no strong feelings of community and belonging. (Company A, interview 4) 
Another metal industry executive described how his company adopted human resources management at the corporate level and developed an integrated matrix organisation structure relying on teamwork. The role of larger units was downgraded; management instead focussed on 'humans'. Teams became the major pole of identification as a way to hinder conflicts:

Teamwork is very essential. There are no other ways of working in this kind of organisational model, because otherwise, it would be full of conflicts. So, yes, these developments towards this - how should I put it? - towards management that has a focus on humans, which does not have a very long history. (Company A, interview 4)

The focus on communal feelings meant that there were attempts to enhance affective bonding and create new compositions. As the companies became flexible and globally networked to survive in new global markets, the importance of rigid and formal hierarchies and organisational structures were diminished. Again, management tried to replace them with affective liaisons, above all, mutual trust, which became a central target of management. With management techniques that emphasised team and company spirit, managers tried to create and encourage new kinds of affective alliances and an affective milieu of trust. Affective management took the form of priming by 'emitting signs' and 'triggering the cues' (Massumi, 2015: 108) trying to activate workers and create ideally joyful compositions filled with friendly relationships in teams. As one executive stated, 'The key word is trust. If you lose that, you've lost everything, and you cannot manage at all any more' (Company C, interview 1). Small, selfdirected teams were also seen as instrumental for avoiding conflicts; although it is impossible to know beforehand what types of composition bodies will form (Thanem and Wallenberg, 2015: 246), it was assumed that conflicts often take place between larger units and hamper organisational life in large corporations.

Moreover, for larger companies, workers were co-opted onto managerial boards. The rationale was that the workers would understand or even feel for their employers' perspectives and develop a feeling of being in the same boat. One executive saw worker co-optation by managerial boards as very useful:

In the 1980s and 1990s, we started to take workers' representatives onto the different levels of managerial boards. In the 2000s, this has become more of a rule than an exception. [...] This has generally led to an increase in mutual understanding, and at the factory level, it has also been experienced positively. I 
do not know of any negative consequences of this practice. (Company $\mathrm{C}$, interview 5)

The new co-optive techniques were also aimed at bypassing the affective alliances that had been sustained by the unions. The trade unions had been a major source of affective alliances in the past. With the new 'focus on humans' and team spirit, management tried to create an affective milieu where workers would feel motivated and forge an affective community with their teams to foster managements' aims. In this new affective milieu, employees would identify with the team, which would create productive and transforming compositions in the organisation.

All in all, management employed a wide range of techniques that attempted to expand to the affective life of the employees (cf. Foucault, 2007 [1977-1978]: 45) in ways that would make employees more productive and manageable in the new market environment. Management attempted to create an affective milieu that educated workers about the dangers of the market, but also guided them and attempted to provide them with feelings of security and meaning. The managers seemed to preserve their being (conatus) by using techniques that tried to instil joyful feelings in their organisation and enhance their employees' capacity (cf. Thanem and Wallenberg, 2015: 241). This kind of affective politics was inductive in nature: it was 'an art of emitting the interruptive signs' and 'triggering the cues' (Massumi, 2015: 108) to activate workers. The aim was not to manage employees through coercion and force; instead, management attempted to modulate employees and establish trusting relationships via positive, inductive power. The human-centred organisational cultures expected employees to turn external pressures into internal dispositions and appropriate affects through self-mastery, individual goal-setting, communication skills and participation in making operational affective milieus. Excellence programmes favoured a bottom-up approach towards development, promising a positive identity for those who achieved goals. Moreover, the management of teams and the co-opting of employees into management boards undermined the old affective alliances based on corporatism and trade unions. Instead, management tried to create and sustain new affective alliances that would undermine the trade unions that had been a more powerful source of affective alliances in the past. Instead, the new management techniques modulated workers' actions by using a range of conditioning triggers (Massumi, 2015: 29-30), creating an affective milieu where employees were expected to self-manage and supervise their work processes and create affective alliances within the company rather than with other workers across similar companies. 


\section{Discussion and conclusions: affectively effective governmentality}

In the current article, we propose that systems of governmentality can be understood as affective milieus that trigger workers and managers to develop subjectivities in constellations crafted by pressures of external economic forces in liberalised market surroundings. In our case, we explored how the Finnish executives' accounts of market liberalisation can be read as a form of Foucauldian governmentality (Foucault, 2007 [1977-1978], 2008 [1978-1979]), attempting to create and sustain a specific milieu (Foucault, 2008 [1978-1979]; Weiskopf and Munro, 2012: 690) where subjects produce the regime of governmentality from within by becoming consenting subjects in the regime.

The liberalised markets forced companies to reformulate their strategies and undertake major restructurings, including closures and layoffs, which, in the words of the executives, became traumatic for the employees. The markets posed new threats as competition tightened, and the managers tried to create new managerial strategies that would encourage their employees to strive and flourish despite cruel and competitive surroundings. Subsequently, numerous management techniques aimed at dealing with the new threats attempted to create a milieu for subjects to take responsibility and embrace risks for their own benefit. Strategic management, the pursuit of core competencies, reliance on information technology and the use of data in management brought home the market threats to employees, signalling the markets' dangers. Employees were expected to understand market logic and perform their tasks as if they had personal ownership of the company. Thus, the subjectivities were linked to the system's aims, as Foucault's (2008 [1978-1979]) ideas on governmentality suggest.

These management techniques clearly entailed affective aspects. According to our case study, in the market environment, managers aim to create an affective milieu oscillating between an unnerving recognition of the all-pervading dangers of the market and techniques for creating feelings of self-realisation and belonging through affective constellations. In particular, Foucault's (2008 [1978-1979]: 66-69) sense of danger seems to become a definitive affective condition in liberalism, creating a sense of threat in liberal regimes. In a market environment, the affective milieu oscillates between danger and security apparatuses. The market creates a sense of danger that can be used to keep workers productive. To counter danger, techniques are applied to monitor, assess and measure the movements of the market, with the aim being to secure companies' positions. At the same time, other techniques attempt to boost workers' positive feelings and motivation and, hence, make them more productive.

Furthermore, in Spinozan-Deleuzian terms, with the threats materialising as layoffs and restructurations, the new affective milieu became characterised by sad feelings such as worry 
and a sense of alarm created by the new market forces (Deleuze, 1988: 26-27; Thanem and Wallenberg, 2015: 241). The liberalising markets created sad feelings because they generated insecurity and ruptured old affective alliances. Yet at the same time, the executives ventured into operations trying to increase joyful feelings. In our case, the management systems aimed to instil positive feelings for the future, worker motivation and communal affectivities. The executives' accounts showed how the new management techniques entailed promises to create joyful affects and encounters and communal feelings in their organisations and, in the Spinozan-Deleuzian vein, to increase employees' motivation and commitment. Thus, our case study shows how affective management in market environments attempts to create milieus of suspense, which may lead to joyful encounters and the capacity to act or to sadness and the diminished capacity to act. These affective politics represented an inductive form of priming 'an art of emitting the interruptive signs' and 'triggering the cues' (Massumi, 2015: 108) - to activate workers.

These governmental techniques can also be seen as affective technologies of the self, serving as 'centrifugal' apparatuses of security addressing dangers and risks by expanding and integrating new ways of doing things (Foucault 2007 [1977-1978]: 45). Foucault's (2008 [1978-1979]) 'entrepreneurial selves' accept the constant risk, rewards and punishments of the market; they take responsibility for risk assessment and their potential failures (Brown, 2015; Fougère et al., 2017), not expecting the state to shield them from risk but rather embracing it (Fougère et al., 2017; Mirowski, 2013: 119).

We argue that the Spinozan-Deleuzian affective theory creates a further possibility for a nuanced understanding of how regimes of governmentality work affectively. The theory helps us understand the complexity and open-endedness of the affective dynamics in market environments oscillating between danger and security apparatuses. Subjects are driven to maintain their existence amid various affections posed by the milieu. In market conditions, management takes the form of priming: Managers condition, incite and orient subjects rather than moulding them into definitive shapes (Massumi, 2015: 41). To counter dangers, management techniques pose threats and require workers to monitor, assess and measure market movements with the aim of securing companies' positions. At the same time, more encouraging management techniques try to promise a meaningful communal life and joyful affects that counter the harshness of market forces.

Our case study shows how the Spinozian-Deleuzian theory can especially enrich our understanding of how these techniques attempt to work. The sad feelings created by the market forced the management to seek new techniques of affective rationality that would ideally prime 
employees to enhance their capacities through joyful encounters and hope. The new management techniques sought to motivate or inspire the employees and tried to encourage feelings of belonging by modulating workers' actions with a range of conditioning triggers (Massumi, 2015: 29-30). Managers tried to create an affective milieu where employees were expected to actively self-manage and supervise their work processes. All this meant understanding the organisation as a composition of entities, where the encounters and constellations may increase or diminish capacities for action (Deleuze, 1988: 77). Indeed, priming requires participation, which allows things to emerge, instead of, for example, punishment, which would diminish communal action (Massumi, 2005: 30).

The new management techniques aimed at making employees not only secure, as Foucault suggests, but also productive, self-reliant and actively seeking to generate joyful and hopeful encounters instead of exploiting sad passions to establish their power (Deleuze, 1988: 25; Thanem and Wallenberg, 2015: 241). The techniques also hoped to use new kinds of affective alliances to undermine the trade unions and replace them with a milieu of teams and managerial boards to enhance affective alliances with the company. The Spinozan-Deleuzian affect theory thus opens up new possibilities for seeing how the joyful element and positive feelings can be part of the management strategies in the workings of governmentality regimes.

The case study also elucidates how the techniques of governmentality could work both rationally and affectively because reason is not separate from affective experience, instead forming part of our affective desires. In both the Foucauldian and Spinozan theories, power works through reason and affect. Foucault addressed affective elements in his writings on the sense of danger and need for security in liberal milieus. Spinoza did not restrict affect to emotion, instead including reason as part of his accounts on how affect works (Thanem and Wallenberg, 2015: 242). As Thanem and Wallenberg (2015: 242) argue, from a Spinozan viewpoint, reason can be seen as the most powerful affect, enabling people to develop an affective understanding of the passions at play. In this case, the rational techniques of core competencies and restructuring and customer satisfaction were used in attempts to create an affective sense of security, while the affective techniques, which attempted to instil forces of joy in the organisation, supported the rationalities of governmentality. Our study indicates that changes in the market can be simultaneously ambivalent and liberating and traumatic for managers. Managers' initiatives often build on charismatic calls for employee empowerment, commitment, spirit building and even revolution (Kantola, 2009), yet at the same time, they almost desperately try to navigate and create survival scenarios in volatile markets. 
In our case, however, it is particularly important to consider that we analysed only the managers' views in this study, and one should also consider the workers' experiences with the regime: How do they adjust to, contribute to or challenge the regime affectively? The present study does not mean that the managers were able to ensure that encounters were joyful and communal in the midst of the threatening market. The interviewees did not explain how affective governmentality actually worked, felt to employees or produced worker subjectivities, instead showing how the executives would have liked it to work and feel. Affective life is irreducible to the ways it is managed; therefore, an affective milieu has ambivalences and surprises; subjects often do not respond with the expected affect. We thus can only show how managers try to create a certain affective milieu to organise and control organisations' affective milieu/life. However, we do not know how the workers actually feel, and this felt experience with governmentality must also be studied.

Future research should explore the various ways management is experienced - how workers enact, contest, resist, take up and modify management and how management is transformed into an affective milieu other than what managers try to create. Indeed, the attempts of management can - and very often - fail, resulting in affective milieus that counter the efforts of management. Managers who try to create attachment and enthusiasm can end up with sad feelings, with frustrated and suspicious workers filled with sadness and resentment (Deleuze, 1998: 26). Empirical studies on restructuring processes show that organisational restructuring (McKinley and Scherer, 2000) often has severe consequences for many organisational members in the form of commitment problems (Probst, 2003), decreased feelings of job security (Reilly et al., 1993) and a decline in trust and job satisfaction (Lee and Teo, 2005); these negative affects may have adverse influences on corporate performance (Bowman and Singh, 1993; Bowman et al., 1999; Brickley and Van Drunen, 1990). It is equally possible that a work culture of enthusiasm will emerge or that a work culture of coercive indoctrination will develop (Tourish, 2013: 41).

The unexpected consequences of management's attempts are an especially crucial issue when thinking affect in the context of governmentality studies, which have been criticised for being too simplistic and assuming that technologies of self actually work in the ways intended. This is, of course, not necessarily the case, and affects cannot be imposed on individuals uniformly. Affects can be effective tools of governmentality, helping motivate subjects and collectivities, but they can also fail, producing results very different from the aims of management. Thus, affect opens up the determinism of governmentality and shows how workers can feel different than expected; in other words, their felt experiences can deviate from 
those suggested by management although workers seem to work in concert with management. These possibilities call for further research to analyse not only attempts at control and management, but also felt affective states from critical perspectives.

At the same time, the open-ended nature of the affect theory makes it possible to search for possibilities for political action. Affective milieus are also uncontrollable: It is impossible to fully predict or calculate how bodies affect and are affected (Thanem and Wallenberg, 2015: 242), and one should explore the indeterminism, contradictions and ambivalence of affective milieus in regimes of governmentality. Because an affective milieu has ambivalences and surprises, subjects can respond creatively and productively generate affects that contribute to the sustenance of the regimes of governmentality. This means that the affect theory entails a political element; there is always space for surprising political action because 'the underlying politics' of Spinoza's affective theory of power 'cannot be exaggerated' (Thanem and Wallenberg, 2015: 241). This understanding can provide a new, enriching approach towards governmentality studies, allowing subjects more space to take unexpected possibilities for action (Deleuze, 1988: 17-18; Karppi et al., 2016) and sometimes develop new ways of breaking out of oppressive regimes (Pullen et al., 2017; Thanem and Wallenberg, 2015).

Thus, further research is needed to understand how milieu-making occurs among and feels to workers and whether this inductive mode of power as priming opens up possibilities for affective communal feelings or even counterpower. Indeed, the organisation of affective life through apparatuses of power is a complex process and cannot be understood only from the analysis of managerial experiences. This is an especially crucial - and perhaps a welcomed point in governmentality studies, which often assume that technologies of self work in the intended ways. Affects can be effective tools of governmentality, helping motivate subjects and collectivities, but they can also fail and produce results that contrast management's aims. 


\section{References}

Anderson B (2014) Encountering Affect. Capacities, Apparatuses, Conditions. Farnham: Ashgate.

Anthonsen M, Lindvall J and Schmidt-Hansen U (2011) Social democrats, unions and corporatism: Denmark and Sweden compared. Party Politics 17(1): 118-134.

Bowman EH, Singh H, Useem M and Bhadury R (1999) When does restructuring improve economic performance? California Management Review 41(2): 33-54.

Bowman EH and Singh H (1993) Corporate restructuring: Reconfiguring the firm. Strategic Management Journal 14(S1): 5-14.

Brennan T (2004) The Transmission of Affect. Ithaca: Cornell University Press.

Brickley JA and Van Drunen LD (1990) Internal corporate restructuring: An empirical analysis. Journal of Accounting and Economics 12(1-3): 251-280.

Brown W (2015) Undoing the Demos: Neoliberalism's Stealth Revolution. New York: Zone Books.

Burawoy M (1979) Manufacturing Consent: Changes in the Labor Process under Monopoly Capitalism. Chicago: University of Chicago Press.

Burchell G (1993) Liberal government and techniques of the self. Economy and Society 22(3): 267-282.

Burchell G, Gordon C and Miller P (eds) (1991) The Foucault Effect: Studies in Governmentality. Chicago: University of Chicago Press.

Christiansen PM (2017) Still the corporatist darlings? In: Nedergaard P and Wivel A (eds) The Routledge Handbook of Scandinavian Politics. New York: Routledge, pp.3649.

Clegg SR, Courpasson D and Phillips N (2006) Power and Organizations. London: Sage.

Dean M (1999) Governmentality: Power and Rule in Modern Society. London: Sage.

Deleuze G (1988) Spinoza: Practical Philosophy. Hurley R (trans). San Francisco: City Lights Books. 
Du Gay P, Salaman G and Rees B (1996) The conduct of management and the management of conduct: contemporary managerial discourse and the constitution of the 'competent' manager. Journal of Management Studies 33(3): 263-282.

Fellman S (2003) The role of internal labour markets and social networks in the recruitment of top managers in Finnish manufacturing firms, 1900-1975. Business History 45(3): 1-21.

Fotaki M, Kenny K and Vachhani SJ (2017) Thinking critically about affect in organization studies: Why it matters. Organization 24(1): 3-17.

Foucault M (1988) Technologies of the self. In: Martin L, Gutman H and Hutton P (eds) Technologies of the Self: A Seminar with Michel Foucault. Amherst: University of Massachusetts Press, pp.16-49.

Foucault, M (2007 [1977-1978]) Security, Territory, Population: Lectures at the Collège de France 1977-1978. Senellart M (ed), Burchell G (trans). New York: Palgrave Macmillan.

Foucault, M (2008 [1978-1979]) The Birth of Biopolitics: Lectures at the Collège de France 1978-1979. Senellart M (ed), Burchell G (trans). New York: Palgrave Macmillan.

Fougère M, Segercrantz B and Seeck H (2017) A critical reading of the European Union's social innovation policy discourse: (Re)legitimizing neoliberalism. Organization 24(6): 819-843.

Gordon C (1991) Governmental rationality: An introduction. In: Burchell G, Gordon C and Miller P (eds) The Foucault Effect: Studies in Governmentality. Hemel Hampstead: Harvester Wheatsheaf, pp.1-51.

Grossberg L (2010) Cultural Studies in the Future Tense. Durham: Duke University Press.

Gutman H (1988) Rousseau's confession: A technology of the self. In: Martin L, Gutman $\mathrm{H}$ and Hutton $\mathrm{P}$ (eds) Technologies of the Self: A Seminar with Michel Foucault. Amherst: University of Massachusetts Press, pp.99-120.

Hindess B (1997) Politics and governmentality. Economy and Society 26(2): 257-272. 
Hjerppe R and Larsson M (2006) Growth and profits in Swedish and Finnish big business during the 20th century. In: European Business Performance in the 20th century, XIV International Economic History Congress, Helsinki, Finland, 21-25 August 2006.

Hutton PH (1988) Foucault, Freud and the technologies of the self. In: Martin L, Gutman $\mathrm{H}$ and Hutton $\mathrm{P}$ (eds) Technologies of the Self: A Seminar with Michel Foucault. Amherst: University of Massachusetts Press, pp.121-144.

Kantola A (2009) The rise of charismatic authority styles in corporate capitalism. Journal of Political Power 2(3): 423-440.

Karppi T, Kähkönen L, Mannevuo M, Pajala M and Sihvonen T (2016) Affective capitalism: Investments and investigations. Ephemera: Theory and Politics in Organization 16(4): 1-13.

Knights D and McCabe D (2003) Governing through teamwork: Reconstituting subjectivity in a call centre. Journal of Management Studies 40(7): 1587-1619.

Lee $\mathrm{G}$ and Teo A (2005) Organizational restructuring: Impact on trust and work satisfaction. Asia Pacific Journal of Management 22(1): 23-39.

Lemke T (2001) 'The Birth of Bio-politics': Michel Foucault's Lecture at the Collège de France on Neoliberal Governmentality. Economy and Society 30(2): 190-207.

Lijphart A (2012) Patterns of Democracy: Government Forms and Performance in Thirty-Six Countries, 2nd ed. New Haven: Yale University Press.

Lilja K and Tainio R (2006) Johtaminen suomalaisissa yrityksissä.

Suunnitelmataloudesta kilpailutalouteen. In: Juuti P (ed) Johtaminen eilen, tänään, huomenna. Helsinki: Otava, pp.103-128.

Lindvall J and Sebring J (2005) Policy reform and the decline of corporatism in Sweden. West European Politics 28(5): 1057-1074.

Massumi B (2015) The Power at the End of the Economy. Durham: Duke University Press.

McKinley W and Scherer A G (2000) Some unanticipated consequences of organizational restructuring. Academy of Management Review 25(4): 735-752. 
Michels C and Steyaert C (2017) By accident and by design: composing affective atmospheres in an urban art intervention. Organization 24(1): 79-104.

Miller P and O'Leary T (1987) Accounting and the construction of the governable person. Accounting, Organizations and Society 12(3): 235-265.

Miller P and Rose N (1988) Governing economic life. Economy and Society 19(1): 131.

Miller P and Rose N (2008) Governing the Present: Administering Economic, Social and Personal Life. Cambridge: Polity.

Mirowski, P (2013) Never Let a Serious Crisis Go to Waste. London: Verso.

Munro I (2012) The management of circulations: Biopolitical variations after Foucault. International Journal of Management Reviews 14(3): 345-362.

Munro I and Randall J (2007) 'I don't know what I'm doing, how about you?':

Discourse and identity in practitioners dealing with the survivors of childhood sexual abuse. Organization 14(6): 887-907.

O’Malley P (2008) Responsibilization. In: Wakefield A and Fleming J (eds) The Sage Dictionary of Policing. London: Sage, pp.276-278.

Probst TM (2003) Exploring employee outcomes of organizational restructuring: A Solomon four-group study. Group \& Organization Management 28(3): 416-439.

Pullen A, Rhodes C and Thanem T (2017) Affective political in gendered organizations: affirmative notes on becoming woman. Organization 24(1): 105-123.

Reilly AH, Brett JM and Stroh LK (1993) The impact of corporate turbulence on:

Managers' attitudes. Strategic Management Journal 14(S1): 167-179.

Rose N (1999) Powers of Freedom: Reframing Political Thought. Cambridge:

Cambridge University Press.

Sedgwick EK (2003) Touching Feeling: Affect, Pedagogy, Performativity. Durham: Duke University Press.

Seeck H and Kantola A (2009) Organizational control: restrictive or productive? Journal of Management and Organization 15(2): 241-257. 
Seigworth GJ and Gregg M (2010) An inventory of shimmers. In: Gregg M and Seigworth GJ (eds) The Affect Theory Reader. Durham: Duke University Press, pp.1-25. Seyfert R (2012) Beyond personal and collective feelings: Towards a theory of social affect. Theory, Culture and Society 26(9): 27-46.

Spinoza BD (1994 [1667]) The Ethics and Other Works. Curley E (trans). Princeton: Princeton University Press.

Thanem, T (2009) 'There's no limit to how much you can consume': The New Public Health and the struggle to manage healthy bodies. Culture and Organization 15(1), 5974.

Thanem $\mathrm{T}$ and Wallenberg L (2015) What can bodies do? Reading Spinoza for an affective ethics of organizational life. Organization 21(2): 235-250.

Tourish D (2013) The Dark Side of Transformational Leadership. A Critical Perspective. London: Routledge.

Weiskopf R and Munro I (2012) Management of human capital: discipline, security and controlled circulation in HRM. Organization 19(6): 685-702. 
Appendix 1: Company profiles

\begin{tabular}{|c|c|c|c|c|}
\hline Company & Industry & Founded & Main business/Product & Number of employees and location \\
\hline A & metal & 1914 & $\begin{array}{l}\text { Started as a mining company that } \\
\text { specialized in mining and upgrading of } \\
\text { ore. Later product range grew to } \\
\text { include manufacturing various new } \\
\text { metals and metal products. After } \\
\text { incorporating business sectors in the } \\
\text { 1990s, it gradually sold all side } \\
\text { businesses and focused on stainless } \\
\text { steel. }\end{array}$ & $\begin{array}{c}\text { Operates in } 34 \text { countries and } \\
\text { employs } 8,000 \text { people worldwide. }\end{array}$ \\
\hline B & metal & 1960 & $\begin{array}{l}\text { Also started as a mining company } \\
\text { specializing in mining and upgrading } \\
\text { of ore. Later product range grew to } \\
\text { include manufacturing various new } \\
\text { metals and metal products. Today, has } \\
\text { diversified its product range from plain } \\
\text { steel to various metal-based } \\
\text { components, systems construction and } \\
\text { mechanical engineering industries. }\end{array}$ & $\begin{array}{l}\text { Facilities in } 27 \text { countries, and } \\
11,700 \text { employees worldwide. }\end{array}$ \\
\hline $\mathrm{C}$ & forest & $\begin{array}{l}1995 \text { as a } \\
\text { result of a } \\
\text { merger }\end{array}$ & $\begin{array}{l}\text { Operates in the field of printing paper, } \\
\text { such as magazine paper, newsprint and } \\
\text { speciality papers, and in the fields of } \\
\text { self-adhesive label materials, wood } \\
\text { products and pulp production. }\end{array}$ & $\begin{array}{l}\text { Operates globally and has } \\
\text { concentrated its production facilities } \\
\text { in } 15 \text { countries, employing more } \\
\text { than } 20,000 \text { people worldwide. }\end{array}$ \\
\hline $\mathrm{D}$ & forest & 1851 & $\begin{array}{l}\text { Previously operated in the sawmill, } \\
\text { paper and paperboard industries as well } \\
\text { as in the engineering and glass } \\
\text { industries. At the beginning of the } 21 \mathrm{st} \\
\text { century, the company was divided into } \\
\text { three separate companies under the } \\
\text { same business group and focused its } \\
\text { operations on speciality papers and } \\
\text { fibre composites. }\end{array}$ & $\begin{array}{l}\text { Production facilities in } 20 \text { countries, } \\
\text { employing more than 5,200 people } \\
\text { worldwide. }\end{array}$ \\
\hline
\end{tabular}




\section{Appendix 2: Profile of the participants}

\begin{tabular}{|c|c|c|c|}
\hline Company & Current/most recent position & Educational Background & Age \\
\hline \multicolumn{4}{|l|}{ A, Metal } \\
\hline A1 & CFO, Vice Chairman & Business Administration and law & 49 \\
\hline $\mathrm{A} 2$ & $\begin{array}{l}\text { Deputy CEO and Deputy } \\
\text { President }\end{array}$ & Business Administration and law & 64 \\
\hline A3 & R\&D Leader & Engineering, MPhil (Tech.) & - \\
\hline A4 & $\begin{array}{l}\text { Investor relations \& corporate } \\
\text { development, Senior Vice } \\
\text { President }\end{array}$ & - & - \\
\hline A5 & Executive Vice President, R\&D & Doctor of Technology & - \\
\hline A6 & Chairman & Engineering & 69 \\
\hline A7 & Executive Vice President & & \\
\hline A8 & Chairman & Engineer and $\mathrm{PhD}$ in philosophy & 73 \\
\hline A9 & Deputy CEO & Business Administration & 62 \\
\hline A10 & Chairman of the Board & $\begin{array}{l}\text { Honorary doctorate degrees in Engineering and } \\
\text { Business Administration }\end{array}$ & 62 \\
\hline A11 & CEO & Engineering, BA* & 72 \\
\hline A12 & $\begin{array}{l}\text { Chief Executive Officer, Board } \\
\text { Member }\end{array}$ & Doctor of Technology & 69 \\
\hline A13 & Vice President, HR & Psychology & - \\
\hline A14 & Executive Vice President, HR & Business Administration & 60 \\
\hline A15 & CEO & Economics, MBA & 56 \\
\hline \multicolumn{4}{|l|}{ B, Metal } \\
\hline B1 & CEO & Business Administration & 55 \\
\hline B2 & $\begin{array}{l}\text { R\&D manager, Senior Vice } \\
\text { President }\end{array}$ & - & - \\
\hline B3 & $\mathrm{CFO}$ & Law & 60 \\
\hline B4 & $\begin{array}{l}\text { Executive Vice President, } \\
\text { administration }\end{array}$ & Engineering & 63 \\
\hline B5 & Chairman of the Board & Engineering & 87 \\
\hline
\end{tabular}




\begin{tabular}{cllc}
\hline \multicolumn{5}{c}{ (previously CEO) } & & \\
\hline B6 & President \& CEO & Law & 69 \\
\hline B7 & Deputy CEO (previously & Economics & 55 \\
& CFO) & & - \\
& & & 43 \\
\hline B8 & Chairman of the Board & Technology & \\
\hline & Senior $\quad$ Vice & President, & Business Administration \\
& & &
\end{tabular}

\begin{tabular}{|c|c|c|c|}
\hline C, Forest & & & \\
\hline $\mathrm{C} 1$ & $\begin{array}{l}\text { Chief Executive President, HR, } \\
\text { Wood Industry }\end{array}$ & Psychology, MBA & 56 \\
\hline $\mathrm{C} 2$ & Chairman & Engineering, Doctor of Technology & 71 \\
\hline C3 & Chairman (previously CEO) & Law & 66 \\
\hline $\mathrm{C} 4$ & $\begin{array}{l}\text { Executive Vice President of } \\
\text { Technology }\end{array}$ & $\begin{array}{l}\text { Engineering, Tech Licentiate, Honorary Doctor of } \\
\text { Science in Technology }\end{array}$ & 60 \\
\hline $\mathrm{C} 5$ & CEO & $\begin{array}{l}\text { Business Administration, Honorary Doctor of } \\
\text { Technology }\end{array}$ & 54 \\
\hline C6 & Deputy President & $\begin{array}{l}\text { Engineering, Honorary Doctor of Science in } \\
\text { Technology }\end{array}$ & 54 \\
\hline $\mathrm{C} 7$ & $\mathrm{CFO}$ & Economics & - \\
\hline D, Forest & & & \\
\hline D1 & CEO & Engineering & 68 \\
\hline D2 & Board member & Engineering & 72 \\
\hline$\overline{\mathrm{D} 3}$ & $\begin{array}{l}\text { Senior vice president, } \\
\text { Innovation }\end{array}$ & $\mathrm{BA}$ & 63 \\
\hline D4 & CEO & Economics, MBA & 47 \\
\hline
\end{tabular}

i Foucault's determinism has been under debate. Governmentality has been criticised for assuming a deterministic view of the technologies of self (e.g. Grossberg, 
2010), as has, for example, the concept of 'discourse' in his earlier work (Fox, 1998).

However, counterviews exist (Gordon, 1991; Thanem, 2009). We are inclined to align with the latter. 